\title{
Perbandingan Efektivitas Model Pembelajaran Problem Based Learning Dengan Model Problem Solving Terhadap Kemampuan Berpikir Kritis Pada Pembelajaran PPKn
}

\section{Dhea Fatar Kiranadewi ${ }^{*}$, Agustina Tyas Asri Hardini²}

1,2 Universitas Kristen Satya Wacana, Salatiga, Indonesia

\section{ART ICLE INFO}

\section{Article history:}

Received February 02, 2021

Revised February 23, 2021

Accepted March 20, 2021

Available online April 25, 2021

Kata Kunci:

PBL, Problem Solving, Berpikir Kritis

\section{Keywords:}

PBL, Problem Solving, Critical

Thinking

\section{A B S T R A K \\ Berdasarkan hasil pengamatan ditemukan permasalahan kemampuan} berpikir kritis siswa yang rendah pada pelaksanaan pembelajaran PPKn, sehingga diperlukan model pembelajaran yang mampu melatih kemampuan berpikir kritis siswa. Tujuan penelitian ini untuk menganalisis ada tidaknya perbedaan tingkat efektivitas antara model problem-based learning dan Problem Solving dalam meningkatkan kemampuan berpikir kritis belajar PPKn siswa di kelas IV SD. Jenis penelitian eksperimen semu (quasi experiment design) yang menggunakan teknik analisis deskriptif. Desain penelitian pola nonequivalent control group design, uji hipotesis penelitian ini menggunakan uji T independent Sample $T$ test. Subyek penelitian yaitu kelas IV dengan jumlah siswa 58 yang meliputi 28 siswa kelas IV SD. Metode pengumpulan data yang digunakan adalah pemberian tes kepada siswa. Dari hasil nilai postest teknik analisis data yang digunakan adalah teknik analisis data statistik kuantitatif. Hasil penelitian ini menunjukkan pengujian hipotesis dengan uji T sig. (2-tailed) diperoleh 0,000 yang artinya lebih kecil dari $0,05(0,000<0,05)$ dengan thitung $5,902>t_{\text {tabel }} 2,002$, dan nilai rata-rata penggunaan model problem based learning yaitu 80,00 yang mengalami peningkatan sedang dengan nilai N-Gain 0,48, sedangkan nilai rata-rata lebih rendah dari model Problem solving yaitu 69,50 dengan nilai N-Gain 0,23. Simpulan penelitian ini adalah model problem based learning terbukti lebih efektif dalam peningkatan kemampuan berpikir kritis PPKn pada siswa dibandingkan menggunakan model Problem Solving.

\section{A B S T R A C T}

Based on the observations, it was found that the problem of students 'low critical thinking skills in the implementation of PPKn learning, so that a learning model is needed that is able to train students' critical thinking skills. The purpose of this study was to analyze whether there is a difference in the level of effectiveness between the problem based learning and Problem Solving Models in improving students' critical thinking skills in learning PPKn in grade IV SD. This type of quasi-experimental research (quasi experiment design) uses descriptive analysis techniques. The research design pattern is nonequivalent control group design, the research hypothesis is tested using the independent $T$ test Sample $T$ test. The research subjects were grade IV with 58 students including 28 grade IV SD students. The data collection method used was giving tests to students. From the results of the posttest value the data analysis technique used is quantitative statistical data analysis techniques. The results of this study indicate hypothesis testing with the $T$ sig test. (2-tailed) obtained 0.000, which means that it is smaller than $0.05(0.000<0.05)$ with tcount $5.902>$ ttable 2.002 , and the average value of using the problem-based learning model is 80.00 which has a moderate increase with the value of $N$-Gain 0.48, while the average value is lower than the problem solving model, namely 69.50 with an $\mathrm{N}$-Gain value of 0.23 . The conclusion of this research is that the problem based learning model is proven to be more effective in increasing the critical thinking skills of PPKn in students compared to using the Problem Solving model..

\section{Pendahuluan}

Pelaksanaan pembelajaran saat ini menggunakan kurikulum 2013, yang secara matang berjalan dan diimplementasikan di sekolah negeri maupun swasta sebagai pengganti kurikulum tingkat satuan

\footnotetext{
Copyright (C) Universitas Pendidikan Ganesha. All rights reserved
} 
pendidikan (KTSP). Semua kegiatan pembelajaran di sekolah khususnya tahun pelajaran 2020/2021 dilaksanakan secara terpadu dengan muatan pembelajaran tematik. Kebijakan pelaksanaan kurikulum 2013 menitik beratkan pada kemampuan anak berpikir tingkat tinggi atau dikenal dengan istilah HOTS (Higher Order Thingking Skills) (Morelent \& Syofiani, 2018; Mulyadin, 2016; Sugiyanto et al., 2015). Hal tersebut menjadikan suatu tantangan tersendiri bagi para guru dalam menerapkan kurikulum 2013 karena guru dituntut mengajari anak dalam berpikir yang tidak biasa atau lebih ke arah berpikir kritis. Pelaksanaan kurikulum 2013 di sekolah dengan muatan pembelajaran tematik menuntut siswa lebih aktif, kegiatan pembelajaran harus memberikan pengalaman belajar yang bermakna dan berkesan dengan model pembelajaran yang sesuai dengan kurikulum 2013 (Machali, 2014; Prasetyo et al., 2016; Resbiantoro, 2016). Model pembelajaran yang tepat pastinya akan bermanfaat bagi guru dan siswa dalam pelaksanaan kegiatan belajar mengajar terutama pada mata pelajaran yang utama seperti PPKn.

Berdasarkan kegiatan wawancara dan pengamatan permasalahan yang ada disekolah khususnya kelas IV pada mata pelajaran PPKn ditemukan permasalahan kemampuan berpikir kritis yang rendah. Hal ini berdampak siswa mengalami permasalahan ketika menjawab soal PPKn karena pada kurikulum 2013 soal sudah dibuat dalam bentuk HOTS (Higher Order Thinking Skills) dan terlihat pemahaman siswa rendah terhadap soal dalam bentuk HOTS (Higher Order Thinking Skills). Permasalahan rendahnya kemampuan berpikir kritis membuat penulis merasa prihatin sehingga dibutuhkan solusi yang cepat dan tepat untuk meningkatkan kemampuan berpikir kritis. Penyebab rendahnya berpikir kritis juga dari model pembelajaran yang digunakan guru masih menggunakan metode ceramah saat mengajar. Hal ini terlihat tidak adanya kegiatan berdiskusi, tanya jawab dan presentasi dalam pembelajaran. Guru juga kurang memberikan media pembelajaran yang menarik supaya siswa semakin terasah kemampuan berpikir kritisnya hal ini terlihat dari guru hanya menggunakan buku tematik saja sebagai pegangan dalam mengajar.

PPKn merupakan salah satu mata pelajaran yang mengajarkan siswa dalam berpikir kritis. Memecahkan masalah pelajar harus berpikir, mencobakan hipotesis dan bila berhasil memecahkan masalah itu ia mempelajari sesuatu yang baru (Astawa et al., 2020; Larasati \& Gafur, 2018; Wiyasa, 2018). Mengingat pentingnya muatan mata pelajaran PPKn di sekolah maka perlu adanya Tindakan yang cepat dan tepat untuk meningkatkan kemampuan berpikir kritis siswa pada mata pelajaran PPKn.Pemilihan model pembelajaran yang tepat dalam meningkatkan kemampuan berpikir kritis merupakan hal yang sangat penting. Model pembelajaran yang menekankan pada keaktifan siswa sehingga daya kemampuan berpikir kritisnya meningkat merupakan suatu modal utama guru dalam mengajar pada kurikulum 2013 (Ardianingsih et al., 2017; Krissandi \& Rusmawan, 2015; Kurniaman \& Noviana, 2017). Model pembelajaran yang memiliki karakteristik pembelajaran tersebut salah satunya yaitu model problem based learning yang berpengaruh pada keaktifan dan peningkatan berpikir kritis siswa dalam mata pelajaran PPKn dengan menciptakan suasana yang aktif untuk siswa. Model pembelajaran problem based learning $(P B L)$ atau solusi masalah adalah model pembelajaran yang menerapkan pola pemberian masalah atau kasus kepada siswa untuk diselesaikan, karena model problem based learning menghadapkan siswa pada suatu permasalahan nyata yang terdapat di lingkungan sebagai dasar untuk memeperoleh pengetahuan melalui kemampuan berpikir kritis dan memecahkan masalah (Fitri et al., 2020; Juliawan et al., 2017; Maryatun \& Metro, 2017). Model ini mempunyai kelebihan untuk melatih siswa dalam meningkatkan kemampuan berfikir kreatif, imajinatif, refleksi, tentang model dan teori, dan mengenalkan dan mencoba gagasan baru, serta mendorong siswa untuk memperoleh kepercayaan diri (Adawiyah, 2018; Pratiwi \& Setyaningtyas, 2020; Suryawati et al., 2020).

Selain itu, model pembelajaran yang dapat diterapkan pada pembelajaran PPKn yaitu model problem solving yang dapat mengembangkan dan mendorong siswa untuk berpikir kritis mencari dan memecahkan masalah. Problem solving adalah suatu model pembelajaran yang menggunakan masalah dunia nyata sebagai suatu konteks bagi siswa untuk belajar tentang cara berfikir kritis dan keterampilan pemecahan masalah, serta memperoleh pengetahuan dan konsep yang esensial dan materi pembelajaran (Purwati et al., 2018; Sidiq \& Prasetyo, 2020; Wasiran \& Andinasari, 2019). Pemilihan kedua model yakni model Problem Based Learning maupun model problem solving perlu diuji efektifitas dalam kegiatan pembelajaran dengan tujuan meningkatkan kemampuan berpikir kritis siswa kelas IV, sehingga kedua model perlu diuji disekolah yang mengalami permasalahan kemampuan berpikir kritis rendah. Penelitian ini diperkuat oleh penelitian terdahulu yaitu: (1) penelitian yang dilakukan oleh (Herzon et al., 2018), yang mendapatkan hasil penelitian bahwa problem based learning berpengaruh terhadap keterampilan berpikir kritis siswa; (2) penelitian yang dilakukan oleh (Falach, 2016), yang mendapatkan hasil penelitian bahwa model pembelajaran problem solving lebih efektif dibandingkan dengan problem posing dalam pembelajaran matematika; (3) penelitian yang dilakukan oleh (Ariswati, 2018), yang mendapatkan hasil penelitian bahwa model pembelajaran problem based learning terhadap hasil belajar matematika siswa. Tujuan penelitian ini untuk menganalisis ada tidaknya perbedaan tingkat efektivitas antara Model 
Problem Based Learning dan Problem Solving dalam meningkatkan kemampuan berpikir kritis belajar PPKn siswa di kelas IV SD.

\section{Metode}

Jenis penelitian yang digunakan adalah penelitian eksperimen semu (quasi experiment design). Penelitian ini dilakukan untuk mengetahui perbedaan penerapan model pembelajaran problem-based learning dan problem solving terhadap kemampuan berpikir kritis PPKn siswa kelas IV. Sebagai kelas kontrol akan dilakukan dengan model Problem Solving dan kelas eksperimen dengan model problembased learning. Penelitian ini dilaksanakan di SD Negeri Bringin 01 sebagai kelas kontrol dan SD Negeri Bringin 02 sebagai kelas eksperimen. Subyek penelitian yaitu kelas IV dengan jumlah siswa 58 yang meliputi 28 siswa kelas IV SD Negeri Bringin 02 dan 30 siswa kelas IV SD Negeri Bringin 01. Hal ini akan dilaksanakan sesuai dengan desain penelitian yaitu pola nonequivalent control group design. Peneliti mengawali penelitian ini dari melihat skor pretest pada kedua kelompok kelas yang dilakukan 1 kali. Dengan pemberian pretest dapat digunakan untuk mengetahui kemampuan awal pada siswa, sebelum diberikan perlakuan.

Metode pengumpulan data yang digunakan adalah pemberian tes kepada siswa. Pada kelompok kontrol akan diberikan perlakuan dengan menggunakan model pembelajaran problem solving dan pada kelompok eksperimen menggunakan model pembelajaran problem based learning, kemudian pada kedua kelas akan diberikan postest. Dari hasil nilai postest digunakan untuk mengetahui pengaruh perbedaan antara kedua model dengan menggunakan teknik analisis data statistik kuantitatif. peneliti menggunakan uji $\mathrm{T}$ independent Sample $T$ test untuk menguji hipotesis pada penelitian ini dengan tujuan untuk memperoleh informasi adanya perbedaan efektivitas antara kedua kelompok yang diberi treatmen yang berbeda terhadap kemampuan berpikir kritis PPKn. Hipotesis pada penelitian ini adalah: $\mathrm{H}_{0}$ : Tidak terdapat perbedaan hasil signifikan terhadap kemampuan berpikir kritis PPKn kelas IV SD pada materi keberagaman karakteristi individu antara model problem based learning dengan model problem solving. $\mathrm{H}_{\mathrm{a}}$ : Terdapat perbedaan hasil signifikan terhadap kemampuan berpikir kritis PPKn kelas IV SD pada materi keberagaman karakteristi individu antara model problem based learning dengan model problem solvin

\section{Hasil dan Pembahasan}

Pada Penelitian ini menerapkan dua model pembelajaran yakni problem based learning dan problem solving dengan tujuan mengetahui adanya perbedaan hasil belajar yang signifikan dalam penerapan model pembelajaran problem based learning dan Problem solving pada Tema 8 Daerah Tempat Tinggalku, Subtema 1 Lingkungan Tempat Tinggalku Pembelajaran 3 kelas IV SDN Bringin 01 dan SDN Bringin 02. Berdasarkan data yang diperoleh dari hasil belajar kelompok eksperimen yang menggunakan model problem based learning diperoleh skor rata-rata 61,43 dan skor rata-rata postest 80,00. Pada kelompok kontrol yang menggunakan model problem solivng memperoleh skor pretes 57,17 dan skor skor rata-rata postest 69,50. Dari hasil data tersebut, hasil skor pretest kedua kelompok yang diberikan perlakuan berbeda yaitu kelompok eksperimen sebelum diberikan treatmen menggunakan model Problem Based Learning dan sebelum diberikan treatmen menggunakan model problem solving atau kelompok kontrol terlihat bahwa dari kedua kelompok tersebut memiliki selisih sebesar 4,26. Sedangkan hasil skor postest antara kedua kelompok yang telah diberikan treatmen menggunakan model problem based learning dan kelompok kontrol yang telah diberikan treatmen menggunakan model problem solving dapat dilihat bahwa hasil skor postest dari kedua kelompok memliki selisih 10,5. Berdasarkan rata-rata kelompok eksperimen lebih unggul dibandingkan skor rata-rata kelompok kontrol. Berikut ini merupakan diagram komparasi data antara kedua kelas dengan treatmen berbeda disajikan dalam bentuk gambar diagram batang dapat dilihat pada Gambar 1.

Dari Gambar 1, dapat diketahui bahwa terdapat peningkatan dari kedua kelompok yaitu kelompok yang diberikan perlakuan model problem based learning atau kelompok eksperimen, maupun kelompok yang diberikan perakuan model pembelajara problem solving atau kelompok kontrol. Pada kelompok eksperimen dapat dilihat skor rata-rata pretes yaitu 61,43 dan skor rata-rata postest yaitu 80.00. sehingga selisih dari skor rata-rata pretest dan postest kelompok eksperimen adalah 18,57. Sedangkan pada kelompok kontrol skor rata-rata pretest adalah 57,17 dan skor rata-rata postest yaitu 69,50. Pada kelompok kontrol dapat diketahui selisih skor rata-rata pretest dan postest adalah sebesar 12,33. Dari data diatas dapat disimplkan bahwa dari kedua kelompok dengan model pembelajaran, problem solving maupun model problem based learning terdapat peningkatan kemampuan berpikir kritis siswa. Data yang diperoleh sebelum dianalisis dilakukan uji prasyarat terlebih dahulu seperti uji normalitas, dan uji homogenitas,Uji normalitas merupakan pengujian yang dilakukan untuk mengetahui pada setiap kelas memiliki distribusi yang normal atau tidak dan menentukan teknik statistic apa yang 
akan digunakan pada pengolahan data berikutnya. Tujuan dari adanya pengujian uji normalitas ini adalah mengetahui penyebaran data dari kedua kelompok yaitu kelompok eksperimen yang diberikan treatmen model Problem Based learning maupun kelompok kontrol yang diberikan treatmen problem solving berdistribusi normal atau tidak. Uji normalitas dalam penelitian ini menggunakan uji Teknik Shapiro-Wilk berbantuan SPSS for Windows 20.

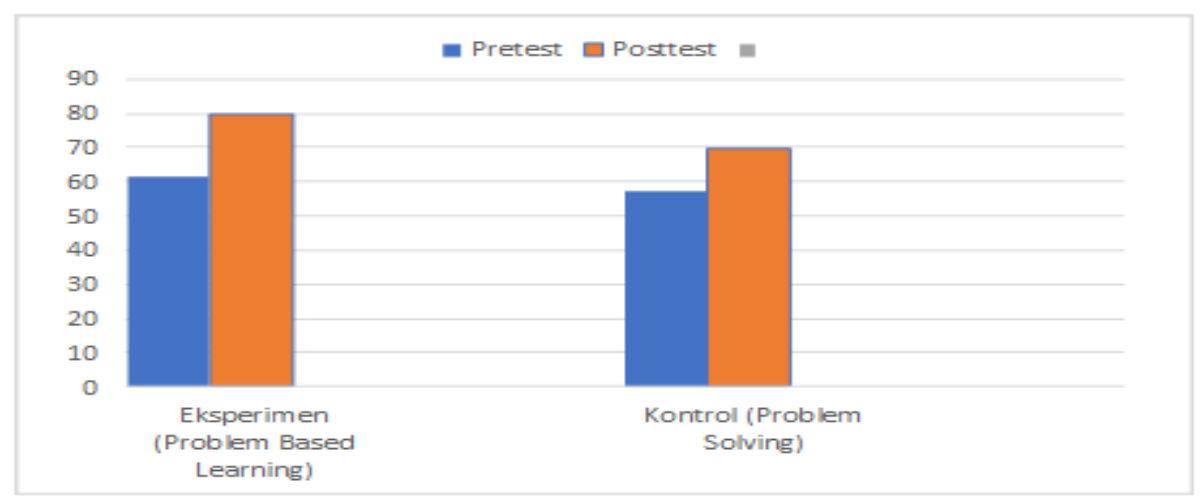

Gambar 1. Hasil Komparasi Hasil Pengukuran

Berdasarkan hasil pengujian normalitas sebelum dan sesudah kedua kelompok pengujian yaitu, kelompok eksperimen dan kelompok kontrol dapat diartikan sebagai berikut: (1) bila nilai nilai signifikansi < 0,05 maka data berdistribusi tidak normal dan sebaliknya; (2) jika nilai signifikansi > 0,05 maka data berdistribusi normal. Berdasarkan hasil pengujian dapat disimpulkan bahwa data berdistribusi normal. Kemudian pada tingkat signifikansi dari nilai kemampuan awal kelompok eksperimen yang menggunakan model problem based learning yaitu 0,097 > 0,05 yang bearti bahwa berdistribusi normal dan tingkat signifikansi nilai posttest kelas eksperimen dengan model problem based learning yaitu 0,074 $>0,05$ hal ini berarti berdistribusi normal. Pada kelompok control dari data diatas dapat dilihat bahwa tingkat signifikansi nilai pretest kelompok kontrol dengan model problem solving yaitu 0,051 > 0,05 yang berarti berdistribusi normal dan tingkat signifikansi nilai postest kelompok eksperimen menggunakan model problem solving yaitu 0,039>0,05 hal ini berarti berdistribusi normal.

Uji homogenitas memiliki tujuan uji homogenitas sampel yaitu untuk mengetahui kondisi data sampel yang diperoleh merupakan sampel berasal dari populasi bervarian homogen ataukah tidak homogen. Hal ini dapat disebut data homogen jika nilai signifikansi > 0,05 dan data tidak homogen jika nilai signifikansi $<0,05$. Berdasarkan tabel menunjukan bahwa uji homogenitas sebelum diberikan perlakuan memperoleh signifikansi 0,546 dimana > 0,05 yang berarti kedua kelompok baik dari kelompok eksperimen maupun kelompok kontrol terdapat variasi yang sama atau dikatakan homogen. Dari hasil uji homogenitas kedua kelompok merupakan kelompok eksperimen dan kelompok kontrol mempunyai varian yang sama atau dianggap homogen. Terlihat dari data diatas menunjukan bahwa uji homogenitas sebelum di berikan perlakuan memperoleh signifikansi 0,157 dimana $>0,05$. Dari uji persyarat yang telah dilakukan, maka dapat disimpulkan bahwa data berdistribusi normal. Selain itu, pada pretest dan postest menunjukan data yang homogen. Kemudian dapat dilakukan analisis menggunakan SPSS 20 for Windows untuk menganalisis uji T menggunakan independent Sample T test. Tujuan dari Uji T yaitu untuk mendapatkan informasi ada atau tidaknya tingkat perbedaan efektivitas antara kedua kelompok baik kelompok eksperimen maupun kelompok kontrol terhadap kemampuan berpikir kritis PPKn.

Hasil analisis uji T yang menggunakan independent sample T test yang menggunakan SPSS 20 for Windows dapat disimpulkan bahwa hasil thitung sebesar 5,902 dan signifikansi pada kolom sig. (2-tailed) sebesar $0,000<0.05$. Selain itu terdapat perbedaan rata-rata antara kelas eksperimen dan kelas kontrol pada kolom mean difference yaitu 12,00. T tabel yang terdapat dari perolehan data diatas adalah 2,002. Berdasarkan hasil tes awal selisih mean kemampuan berpikir kritis siswa antara kedua kelompok eksperimen yang di berikan treatmen model problem based learning lebih tinggi dibandingkan kelompok kontrol yang diberikan treatmen problem solving. Hal ini berarti kelompok eksperimen lebih efektif diterapkan pada pembelajaran dibandingkan dengan kelompok kontrol, sedangkan uji N-Gain dapat memperkuat hasil keefektifan dari penerapan perlakuan kedua model pembelajaran problem based learning dan probem solving. Rata-rata hasil uji $\mathrm{N}$-Gain kelas eksperimen dan kelas kontrol dapat dilihat pada Tabel 1. 
Tabel 1. Rata-rata Hasil Uji N-Gain Kelas Eksperimen dan Kelas Kontrol

\begin{tabular}{ccc}
\hline No & Kelompok & Rata-rata \\
\hline 1 & Eksperimen & 0.48 \\
2 & Kontrol & 0.23 \\
\hline
\end{tabular}

Dari data hasil uji $N$-Gain pada kelas yang di treatmen model problem based learning atau kelas eksperimen menunjukan perubahan peningkatan sebesar 0,48 . Hal ini berarti bahwa skor mean kelas eksperimen mengalami peningkatan pada kategori sedang, sedangkan hasil mean kelas yang diberikan perlakuan menggunakan model problem solving atau kelas kontrol mengalami peningkatan sebesar 0,23 yang berarti juga rata-rata kelompok kontrol mengalami peningkatan peningkatan kategori rendah. Dari data diatas dapat disimpulkan bahwa kelas eksperimen memiliki peningkatan yang lebih tinggi dibandingkan dengan kelompok kontrol. Penelitian ini menerapkan dua model pembelajaran yaitu problem solving dan problem based learning dengan tujuan untuk mengetahui ada atau tidaknya perbedaan hasil belajar yang signifikan dalam penerapan model pembelajaran problem based learning dan problem solving pada Tema 8 Daerah Tempat Tinggalku, Subtema 1 Lingkungan Tempat Tinggalku Pembelajaran 3 kelas IV SD N Bringin 01 dan SD N Bringin 02. Pada kedua model terbukti dapat mengembangkan dan meningkatkan kemampuan berpikir kritis PPKn siswa.Terlihat dari aspek-aspek yang terdapat pada model pembelajaran yang digunakan untuk mengembangkan dan meningkatkan kemampuan berpikir kritis siswa yaitu dengan identifikasi masalah, merumuskan masalah, strategi penyelesaian masalah, pengumpulan data dan menyimpulkan hasilnya.

Selanjutnya, penelitian terlebih dahulu dilakukan dengan kegiatan untuk mengetahui kemampuan awal berpikir kritis. Berikutnya diberikan treatmen menggunakan model problem based learning pada kelas eksperimen dan problem solving pada kelas kontrol. Selanjutnya diberikan postest untuk mengetahui peningkatan pada kemampuan beripikir kritis siswa setelah diberikan perlakuan, supaya terlihat adanya perbedaan nilai yang signifikan.Selain itu, peneliti melakukan analisis dari kedua model pembelajaran, pada model problem solving yang meningkat sebesar $12 \%$ sedangkan model pembelajaran problem based learning mengalami peningkatan sebesar 19\%. Berdasarkan hasil penelitian ini dapat ditarik kesimpulan bahawa model pembelajaran problem based learning lebih efektif untuk meningkatkan dan mengembangkan kemampuan berpikir kritis ppkn siswa karena di dalam penelitian dibandingkan dengan model problem solving. Keberhasilan dalam mengembangkan kemampuan berpikir kritis PPKn siswa di kelas IV dengan model problem based learning dipengaruhi oleh kegiatan pembelajaran yang meminta siswa untuk mencari solusi atau strategi-strategi dalam pemecahan masalah, sehingga model pembelajaran problem based learning sangat berpengaruh positif pada kemampuan siswa dalam meningkatkan kemampuan berpikir kritis.

Model pembelajaran yang memiliki karakteristik pembelajaran tersebut salah satunya yaitu model problem based learning yang berpengaruh pada keaktifan dan peningkatan berpikir kritis siswa dalam mata pelajaran PPKn dengan menciptakan suasana yang aktif untuk siswa. Model pembelajaran problem based learning (PBL) atau solusi masalah adalah model pembelajaran yang menerapkan pola pemberian masalah atau kasus kepada siswa untuk diselesaikan, karena model problem based learning menghadapkan siswa pada suatu permasalahan nyata yang terdapat di lingkungan sebagai dasar untuk memeperoleh pengetahuan melalui kemampuan berpikir kritis dan memecahkan masalah (Fitri et al., 2020; Juliawan et al., 2017; Maryatun \& Metro, 2017). Model ini mempunyai kelebihan untuk melatih siswa dalam meningkatkan kemampuan berfikir kreatif, imajinatif, refleksi, tentang model dan teori, dan mengenalkan dan mencoba gagasan baru, serta mendorong siswa untuk memperoleh kepercayaan diri (Adawiyah, 2018; Pratiwi \& Setyaningtyas, 2020; Suryawati et al., 2020).

Selain itu, model pembelajaran yang dapat diterapkan pada pembelajaran PPKn yaitu model problem solving yang dapat mengembangkan dan mendorong siswa untuk berpikir kritis mencari dan memecahkan masalah. Problem solving adalah suatu model pembelajaran yang menggunakan masalah dunia nyata sebagai suatu konteks bagi siswa untuk belajar tentang cara berfikir kritis dan keterampilan pemecahan masalah, serta memperoleh pengetahuan dan konsep yang esensial dan materi pembelajaran (Purwati et al., 2018; Sidiq \& Prasetyo, 2020; Wasiran \& Andinasari, 2019). Pemilihan kedua model yakni model Problem Based Learning maupun model problem solving perlu diuji efektifitas dalam kegiatan pembelajaran dengan tujuan meningkatkan kemampuan berpikir kritis siswa kelas IV, sehingga kedua model perlu diuji disekolah yang mengalami permasalahan kemampuan berpikir kritis rendah. Penelitian ini diperkuat oleh penelitian terdahulu yaitu: (1) penelitian yang dilakukan oleh (Herzon et al., 2018), yang mendapatkan hasil penelitian bahwa problem based learning berpengaruh terhadap keterampilan berpikir kritis siswa; (2) penelitian yang dilakukan oleh (Falach, 2016), yang mendapatkan hasil penelitian bahwa model pembelajaran problem solving lebih efektif dibandingkan dengan problem posing 
dalam pembelajaran matematika; (3) penelitian yang dilakukan oleh (Ariswati, 2018), yang mendapatkan hasil penelitian bahwa model pembelajaran problem based learning terhadap hasil belajar matematika siswa. Adapun implikasi dari pelaksanaan penelitian ini adalah melatih siswa dalam meningkatkan kemampuan berfikir kreatif, imajinatif, refleksi, tentang model dan teori, dan mengenalkan dan mencoba gagasan baru, serta mendorong siswa untuk memperoleh kepercayaan diri.

\section{Simpulan dan Saran}

Berdasarkan hasil penelitian dan data-data yang diperoleh dapat disimpulkan bahwa model problem based learning (PBL) lebih efektif dalam peningkatan kemampuan berpikir kritis PPKn pada siswa kelas IV di bandingkan dengan model pembelajaran Problem Solving. Implikasi dalam penelitian ini yaitu melatih siswa dalam meningkatkan kemampuan berfikir kreatif, imajinatif, refleksi, tentang model dan teori, dan mengenalkan dan mencoba gagasan baru, serta mendorong siswa untuk memperoleh kepercayaan diri.

\section{Daftar Rujukan}

Adawiyah, R. (2018). Implementasi Metode Problem Based Learning Pada Mata Pelajaran Al-Quran dan Hadist Untuk Meningkatkan Hasil Belajar Kognitif dan Penanaman Sikap Peduli Sosial Pada siswa MTs Negeri 1 Sidoarjo. Pedagogia: Jurnal Pendidikan, 7(1), 61-67. https://doi.org/10.21070/pedagogia.v7i1.1604.

Ardianingsih, F., Mahmudah, S., \& Rianto, E. (2017). Peran Guru Dalam Implementasi Kurikulum 2013 Pendidikan Khusus Pada Sekolah Luar Biasa Di Sidoarjo. Jurnal Pendidikan, 2(1), 14-20. https://doi.org/10.26740/jp.v2n1.p21-30.

Ariswati, N. P. E. A. (2018). Pengaruh Model Pembelajaran Problem Based Learning Terhadap Hasil Belajar Matematika Siswa Kelas V Sd Negeri Nanggulan. Mimbar PGSD, 6(4). https://doi.org/10.1590/s1809-98232013000400007.

Astawa, I. W. W., Putra, M., \& Abadi, I. B. G. S. (2020). Pembelajaran PPKn dengan Model VCT Bermuatan Nilai Karakter Meningkatkan Kompetensi Pengetahuan Siswa. Jurnal Pedagogi Dan Pembelajaran, 3(2), 199-210. https://doi.org/10.23887/jp2.v3i2.25677.

Falach, H. N. (2016). Perbandingan keefektifan pendekatan problem solving dan problem posing dalam pembelajaran matematika pada siswa SMP. Pythagoras: Jurnal Pendidikan Matematika, 11(2). https://doi.org/https://doi.org/10.21831/pg.v11i2.10635.

Fitri, M., Yuanita, P., \& Maimunah, M. (2020). Pengembangan Perangkat Pembelajaran Matematika Terintegrasi Keterampilan Abad 21 Melalui Penerapan Model Problem Based Learning (PBL). Jurnal Gantang, 5(1), 77-85. https://doi.org/10.31629/jg.v5i1.1609.

Herzon, H. H., Budijanto, \& Utomo, D. H. (2018). Pengaruh Problem-Based Learning (PBL) terhadap Keterampilan Berpikir Kritis. Jurnal Pendidikan: Teori, Penelitian, Dan Pengembangan, 3(1), 4246. http://journal.um.ac.id/index.php/jptpp/.

Juliawan, G. A., Mahadewi, L. P. P., \& Rati, W. R. (2017). Pengaruh Model Problem Based Learning (PBL) Terhadap Kemampuan Pemecahan Masalah Matematika. Mimbar PGSD, 5(2), 1-10. https://doi.org/10.23887/jjpgsd.v5i2.10881.

Krissandi, A. D. S., \& Rusmawan, R. (2015). Kendala Guru Sekolah Dasar Dalam Implementasi Kurikulum 2013. Jurnal Cakrawala Pendidikan, 3(3), 457-467. https://doi.org/10.21831/cp.v3i3.7409.

Kurniaman, O., \& Noviana, E. (2017). Penerapan Kurikulum 2013 Dalam Meningkatkan Keterampilan, Sikap, Dan Pengetahuan. Primary: Jurnal Pendidikan Guru Sekolah Dasar, 6(2). https://doi.org/10.33578/jpfkip.v6i2.4520.

Larasati, V., \& Gafur, A. (2018). Hubungan kompetensi pedagogis dan kompetensi profesional guru PPKn dengan prestasi belajar siswa sekolah menengah. Jurnal Civics: Media Kajian Kewarganegaraan, 15(1), 45-51. https://doi.org/10.21831/jc.v15i1.17282.

Machali, I. (2014). Kebijakan Perubahan Kurikulum 2013 dalam Menyongsong Indonesia Emas Tahun 2045. Jurnal Pendidikan Islam, 3(1), 71. https://doi.org/10.14421/jpi.2014.31.71-94.

Maryatun, \& Metro, P. E. F. U. M. (2017). Pengaruh Penggunaan Model Problem Based Learning (PBL) Terhadap Hasil Belajar Ekonomi Siswa Kelas X Semester Genap Sma Pgri 1 Metro Tahun Pelajaran 2016/2017. Jurnal Pendidikan EKonomi, 5(1), 152-159. https://doi.org/10.24127/ja.v5i2.1225.

Morelent, Y., \& Syofiani. (2018). Pengaruh Penerapan Kurikulum 2013 Terhadap Pembentukan Karakter Siswa Sekolah Dasar Negeri 05 Percobaan Pintu Kabun Bukittinggi. Jurnal Penelitian Bahasa Dan Sastra Indonesia, 1(2), 141-152. https://doi.org/10.22202/jg.2015.v1i2.1234.

Mulyadin. (2016). Implementasi Kebijakan Pembelajaran Tematik Terpadu Kurikulum 2013 Di SDN Kauman 1 Malang Dan SD Muhammadiyah 1 Malang. Jurnal Edutama, 3(2), 31-48. 
https://doi.org/10.30734/jpe.v3i2.35.

Prasetyo, A., Hartini, T., Damayani, A., Mushafanah, Q., \& Zahraini, D. A. (2016). IbM Himpaudi Kecamatan Kaliwungu Kendal Dalam Rangka Penyusunan Perangkat Pembelajaran Kurikulum 2013. EDIMAS: Jurnal Pengabdian Kepada Masyarakat, 7(2), 1 - 8. https://doi.org/10.26877/edimas.v7i2.1128.

Pratiwi, E. T., \& Setyaningtyas, E. W. (2020). Kemampuan Berpikir Kritis Siswa SD dengan Model Pembelajaran Problem Based Learning dan Model Pembelajaran Project Based Learning. Jurnal Basicedu, 4(2), 379-388. https://doi.org/10.31004/basicedu.v4i4.445.

Purwati, L., Rochmad, \& Wuryanto. (2018). An Analysis of Mathematical Problem Solving Ability Based on Hard Work Character in Mathematics Learning Using Connecting Organizing Reflecting Extending Model. Unnes Journal of Mathematics Education, 7(3), 195-202. https://doi.org/10.15294/ujme.v7i3.28977.

Resbiantoro, G. (2016). Analisis Pedagogical Content Knowledge (Pck) Terhadap Buku Guru Sd Kurikulum 2013. Scholaria: Jurnal Pendidikan Dan Kebudayaan, 6(3), 153. https://doi.org/10.24246/j.scholaria.2016.v6.i3.p153-162.

Sidiq, M. A., \& Prasetyo, T. (2020). Efektivitas Model Pembelajaran Problem Solving dan Discovery Learning Terhadap Kemampuan Berpikir Kritis Siswa Sekolah Dasar. Jurnal Basicedu, 4(2), 361370. https://doi.org/10.31004/basicedu.v4i2.358.

Sugiyanto, S., Kartowagiran, B., \& Jailani, J. (2015). Pengembangan Model Evaluasi Proses Pembelajaran Matematika Di SMP Berdasarkan Kurikulum 2013. Jurnal Penelitian Dan Evaluasi Pendidikan, 19(1), 82-95. https://doi.org/10.21831/pep.v19i1.4558.

Suryawati, E., Suzanti, F., Zulfarina, Putriana, A. R., \& Febrianti, L. (2020). The implementation of local environmental problem-based learning student worksheets to strengthen environmental literacy. Jurnal Pendidikan IPA Indonesia, 9(2), 169-178. https://doi.org/10.15294/jpii.v9i2.22892.

Wasiran, Y., \& Andinasari. (2019). Meningkatkan Kemampuan Berpikir Kreatif dan Penalaran Adaptif Matematika Melalui Paket Instruksional Berbasis Creative Problem solving. JNPM (Jurnal Nasional Pendidikan Matematika), 3(1), 51-65. https://doi.org/10.33603/jnpm.v3i1.1466.

Wiyasa, I. K. N. (2018). Pengaruh Model Pembelajaran Open Ended Berbasis Penilaian Proyek Terhadap Kompetensi Pengetahuan PPKn Siswa. Jurnal Imiah Pendidikan Dan Pembelajaran, 2(2). https://doi.org/10.23887/jipp.v2i2.15407. 